\title{
PALABRAS PRONUNCIADAS EL 10 DE ENERO DE 1998 EN LA PARROQUIA SAN PEDRO DE COQUIMBO CON OCASIÓN DE LOS FUNERALES DE DON HUGO ZEPEDA BARRIOS, POR DON RENÁN FUENTEALBA MOENA, INTENDENTE IV REGIÓN COQUIMBO
}

No es mucho lo que yo sé de don Hugo Zepeda Barrios, excepto lo que manifesté en la palabras que pronuncié en la Iglesia de Coquimbo con ocasión de sus funerales.

Cuando llegué en 1944 a ésta, entonces, Provincia, hoy Región, él era ya diputado y lo conocí por sus actuaciones como tal, pero sobre todo por referencias de quien era su colega en el estudio que compartían juntos en el puerto, don Eugenio Medina Fernández.

Profesionalmente, nunca dejó de ejercer y atendió algunos asuntos de gran importancia, aún siendo parlamentario. Instaló también oficina en Santiago, pero nunca dejó de estar ligado con su tierra, a la que pertenecía y estaba enlazado por todos sus ancestros Zepeda Barrios. Su esposa Anita, por su parte pertenecía a una familia de agricultores de apellido Coll, y ello los

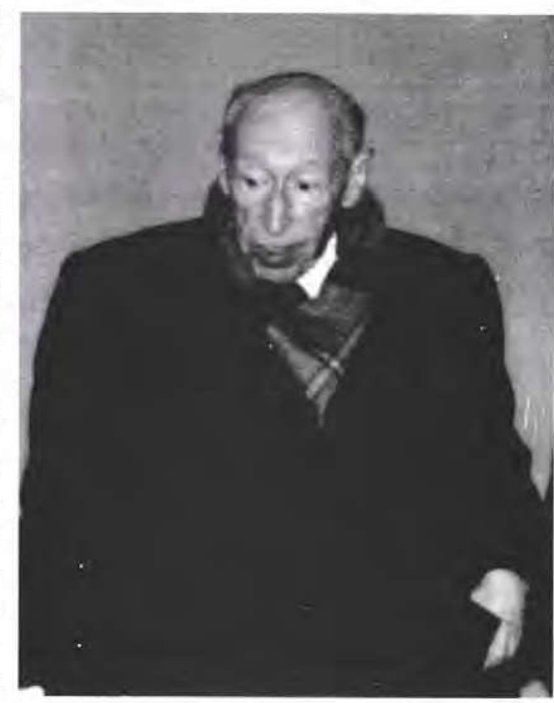
acercaba también a La Serena.

Creo sinceramente que fue un político ejemplar por su espíritu de servicio público y su influencia en el partido Liberal, al cual perteneció siempre, continuando cuando la derecha formó el Partido Nacional. Fue muchas veces Presidente Nacional convirtiéndose en una figura pública de gran relieve. No era ambicioso, fue diputado seis períodos. Pudo disputar a sus correligionarios el cargo de Senador, pero modestamente cedía el paso sin oposición alguna. Sólo cuando falleció Raúl Marín Balmaceda, pasó a ocupar la vacante que se produjo, en una elección extraordinaria en que contó con un amplio apoyo de partidos y ciudadanos. Muy pronto fue elegido Presidente del Senado, pero en marzo de 1965 fue derrotado y perdió la reelección a la cual aspiraba. Desde entonces se dedicó su partido y a sus actividades particulares ejerciendo su profesión en Santiago. Participó también muy activamente en el movimiento que conforman diversas colectividades para lograr lo más pronto el regreso a un gobierno civil democrático. Pero Hugo Zepeda no pedía nada para sí y en sus últimos años se recluyó en Coquimbo donde vivió en La Herradura hasta su fallecimiento a una avanzada edad. 
Revista de Derecho - Universidad Católica del Norte - Sede Coquimbo - 1998

En suma fue un abogado político de gran influencia y liderazgo en su época como fiel militante del partido Liberal, a través del cual sirvió a su tierra y a su patria, con inteligencia, con honestidad, desinterés y sencillez. 